\title{
Crambe (Crambe abyssinica) and sunflower (Helianthus annuus) protein concentrates: production methods and nutritional properties for use in fish feed
}

\author{
NAGLEZI M. LOVATTO ${ }^{1}$, FERNANDA R. GOULART ${ }^{1}$, BRUNO B. LOUREIRO ${ }^{1}$, CAROLINE S. SPERONI ${ }^{2}$, \\ ANA B.B. BENDER ${ }^{2}$, SANDRO J. GIACOMINI ${ }^{3}$, JOÃO RADÜNZ NETO ${ }^{1}$ and LEILA P. DA SILVA ${ }^{1}$ \\ ${ }^{1}$ Laboratório de Piscicultura, Departamento de Zootecnia, Universidade Federal de Santa Maria, \\ Avenida Roraima, 1000, Cidade Universitária, Camobi, 97105-900 Santa Maria, RS, Brazil \\ ${ }^{2}$ Departamento de Tecnologia e Ciência dos Alimentos, Universidade Federal de Santa Maria, Avenida \\ Roraima, 1000, Cidade Universitária, Camobi, 97105-900 Santa Maria, RS, Brazil \\ ${ }^{3}$ Departamento de Ciência do Solo, Universidade Federal de Santa Maria, Avenida Roraima, \\ 1000, Cidade Universitária, Camobi, 97105-900 Santa Maria, RS, Brazil
}

Manuscript received on December 4, 2014; Accepted for publication on December 17, 2015

\begin{abstract}
The purpose of this study was to develop and improve protein concentration techniques for two industrial by-products with the potential for use in fish feed. In particular, we chemically characterized crambe meal and sunflower meal and their protein concentrates. Three different protein concentration methods were tested: isoelectric $\mathrm{pH}(\mathrm{pHi})$, acid $\mathrm{pH}$ and alkaline $\mathrm{pH}$. For crambe and sunflower meals extraction using the pHi method was most efficient in terms of protein yield and crude protein content in the concentrates; this method also increased lysine and methionine content in the concentrates. The water holding capacity of the sunflower protein concentrate was greater than that of the crambe protein concentrate. The crambe protein concentrate had a foam-formation capacity of $15 \%$, which stabilized at $6 \%$ after 90 minutes. The protein concentration method also reduced total phenolic content by approximately $50 \%$ in the concentrates compared with the meals. Therefore, we conclude that protein concentration using the pHi method is the most efficient technique for crambe and sunflower meals, and the use of this technique can decrease total phenolic compounds while improving meal quality for fish feeding.
\end{abstract}

Key words: amino acids, antinutrients, aquafeeds, byproducts, phenolic compounds, protein concentration.

\section{INTRODUCTION}

The exponential increase in the demand for fish feed ingredients, as well the need to improve agricultural efficiency in general, highlights the emergency for practical, efficient and viable solutions for optimizing the use of agricultural byproducts and

Correspondence to: Naglezi de Menezes Lovatto

E-mail: naglezilovatto@hotmail.com residues. Plants byproducts are often underutilized by the animal feed industry, due to either lack of knowledge concerning the nutritional value of these foods or to the presence of intrinsic antinutritional factors (Naylor et al. 2009).

In the world, industrialized food production generates large amounts of organic byproducts, such as vegetable press cake, peels, hulls and meals as well as byproducts from biodiesel production. 
With respect to fish feeds, nutritional studies and applicability these byproducts will be necessary for avoiding potential obstacles to supply chains (Silva et al. 2010). Sunflower (Helianthus annuus) and crambe (Crambe abyssinica) are oleaginous plants that, due to biodiesel production incentives in Brazil, have increased their cultivation in recent years (EMBRAPA 2011).

As fish require more protein in their diets compared with other vertebrates, it is necessary to include large quantities of meal from animal sources, particularly fish meal, in their feed (Wilson 2002). The need for high-protein ingredients in fish feeds poses an obstacle to the use of plant meals such as those derived from soybeans, sunflowers and canola - and increases our dependency on animal-derived protein sources, which are costly, less abundant and heterogeneous between batches (Hardy 2010).

One way to efficiently utilize vegetable-protein sources is to turn them into protein concentrates. However, despite their utility for eliminating or decreasing levels of antinutritional factors and enzymatic inhibitors (Linden and Lorient 1996). Therefore, the production of protein concentrates for use in fish feed from alternative vegetable sources with few or no industrial applications is a promising way of investigation. At lower fiber contents and antinutritional factors than their original products, these concentrates should prove useful as either functional foods or as additives to low-cost foods (Mariod et al. 2010).

The purpose of this study was to develop and optimize techniques for the production of protein concentrates from two industrial byproducts as potential products for use in fish feed. In particular, we chemically characterized sunflower and crambe meals as well as their respective protein concentrates.

\section{MATERIALS AND METHODS}

\section{RAW MATERIALS}

Variety FMS Brilhante crambe press cake was provided by the MS Foundation for Agricultural Technologies Research (Fundação MS para Pesquisas de Tecnologias Agropecuárias, Mato Grosso do Sul, Brazil); the crambe press cake with hulls was degreased with three washes of hexane (F.MAIA Industry and Trade, Cotia, São Paulo, Brazil) in a 2:1 ratio. Pelletized sunflower meal with hulls was provided by the Giovelli ${ }^{\circledR}$ Company; the sunflower meal was ground using a MA-630 Marconi micro mill and forced through a $600-\mu \mathrm{m}$ sieve to remove excess fiber. These two meals were then further processed to obtain the sunflower and crambe protein concentrates.

\section{PROTEIN CONCENTRATION METHODS}

Three different protein concentration methods were tested, as described in Figure 1. Protein extraction using the isoelectric $\mathrm{pH}(\mathrm{pHi})$ method was carried out as described by Smith et al. (1946), with the following changes: 1) The protein was dispersed in an aqueous medium by processing it three times in a blender (LIQ789, Cadence, Brazil) at maximum speed for 3 minutes at room temperature; the meal was blended in water at a ratio of 1:10 - each time. 2) The ground sample was sieved a $140 \mu \mathrm{m}$, and the remaining solid fraction (i.e., the fraction retained in the sieve) was discarded. The liquid fraction was then used for protein extraction. 3) Protein solubilization by isoelectric $p H$ was carried out by increasing the $\mathrm{pH}$ of the liquid sample to 9.0 with $1 \mathrm{~N} \mathrm{NaOH}$. To precipitate the protein, the $\mathrm{pH}$ of the liquid was then reduced to 4.5 with $1 \mathrm{~N} \mathrm{HCl}$.

Protein extraction using the acid $\mathrm{pH}$ method was carried out as described by Modesti et al. (2007), with the above changes (1) and (2), and a final adjustment of the liquid sample to $\mathrm{pH} 4.5$ with $1 \mathrm{~N} \mathrm{HCl}$. 


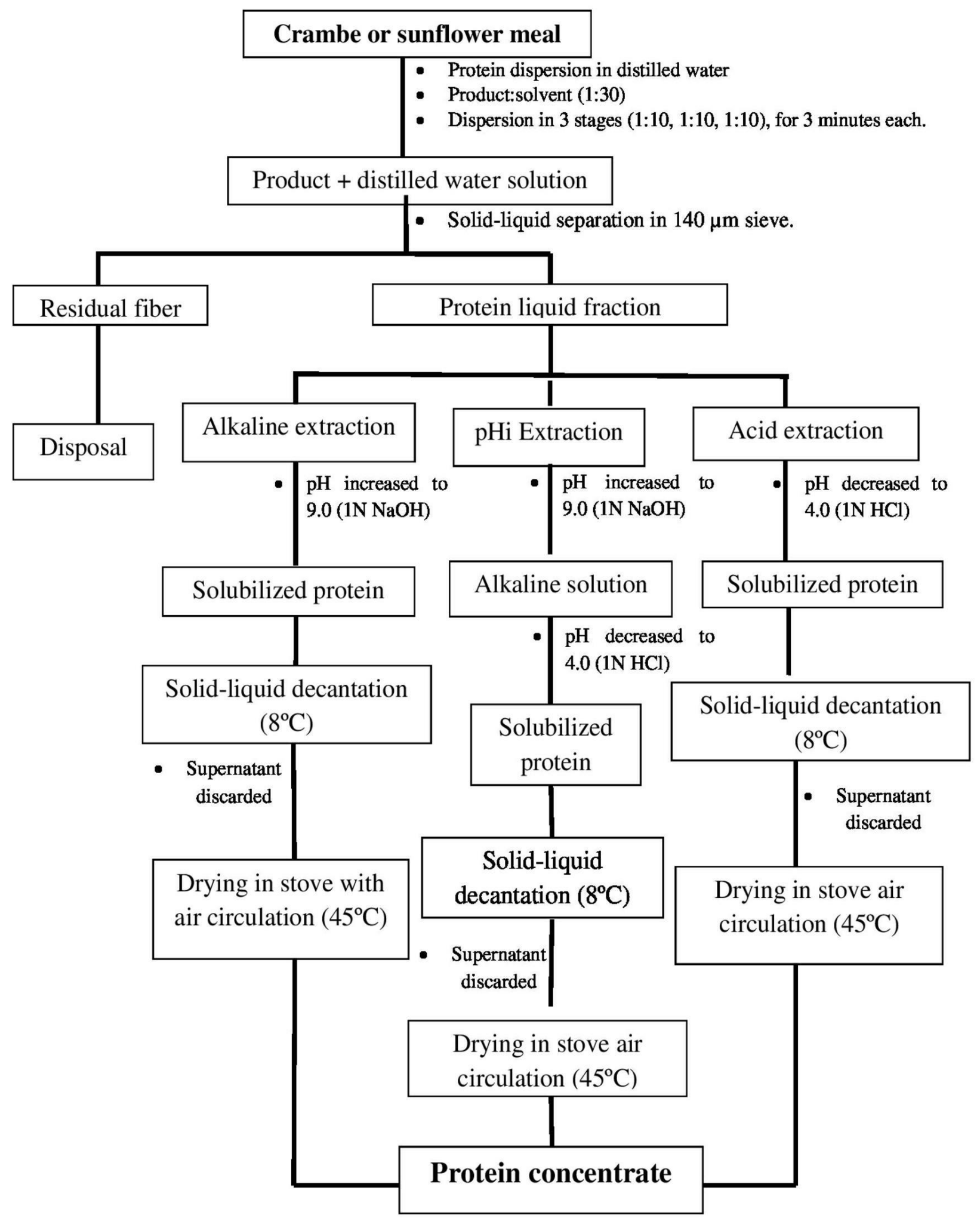

Figure 1 - Protein concentration methods for crambe and sunflower meals: alkaline extraction, extraction by isoelectric $\mathrm{pH}$, and acid extraction. 
Protein extraction using the alkaline $\mathrm{pH}$ method was carried out as described by Modesti et al. (2007), with the above changes (1) and (2), and a final adjustment of the liquid sample to $\mathrm{pH} 9.0$ with $1 \mathrm{~N} \mathrm{NaOH}$.

\section{PROTEIN CONTENT ANALYSIS}

Three protein concentration methods were analyzed to determine their yields (i.e., protein concentrate percentage after drying relative to the sample size used for extraction) by quantifying crude protein content using the Micro-Kjeldahl method $\left(\mathrm{n}^{\circ}\right.$ 920.87; AOAC 2000) with 6.25 as the conversion factor.

\section{DETERMINATION OF CHEMICAL COMPOSITION}

For the method with the highest yield, the following parameters were analyzed for the meals and protein concentrates: moisture, ash (according to methods of the Instituto Adolfo Lutz (1985), crude protein (AOAC 2000) and lipids (Bligh and Dyer 1959). The amino-acid profiles of the products were determined using high performance liquid chromatography (HPLC); sample hydrolysis was carried out in a $6 \mathrm{~N} \mathrm{HCl}$ solution. The amino acids released during hydrolysis were derivatized with phenyl isothiocyanate (PITC), also known as 'precolumn derivatization. The derivatized amino acids were separated using a C18 reverse-phase column $(3.9 \times 300 \mathrm{~mm}$; Pico-Tag) and quantified using UV analysis (at $254 \mathrm{~nm}$ ), as described by White et al. (1986).

\section{DETERMINATION OF PHYSICAL PROPERTIES}

The water holding capacity (WHC) and oil holding capacity $(\mathrm{OHC})$ of the samples were determined as described by Okezie and Bello (1988). Samples were hydrated in distilled water (for WHC) or soy oil (for OHC). After rest (24 h) and centrifugation, excess supernatant was discarded. The results were expressed as the amount of water/oil retained by the sample (in dry matter) per gram (g water/oil / g sample), respectively. The foaming properties were determined as described by Coffmann and Garcia (1977).

\section{DETERMINATION OF PHENOLIC COMPOUNDS}

Total phenolic compounds were analyzed as described by Waterhouse (2001) by the micromethod of Folin-Ciocalteu. Phenolic content was calculated as gallic acid equivalents (GAE) and reported as $\mathrm{mg} / \mathrm{L} \mathrm{DM}$.

\section{EXPERIMENTAL DESIGN AND STATISTICAL ANALYSIS}

A randomized experimental design was used in this study. The results were tested using Analysis of Variance (ANOVA) and the averages were compared using Tukey's test at a 5\% significance level.

\section{RESULTS}

\section{PROTEIN CONCENTRATION METHODS AND CHEMICAL COMPOSITION}

For crambe and sunflower meals, we observed that the isoelectric $\mathrm{pH}$ extraction ( $\mathrm{pHi}$ ) method was the most efficient in terms of the yield and crude protein content of the final protein concentrates (Table I). The protein concentrates were denominated crambe meal protein concentrate (CMPC) and sunflower meal protein concentrate (SMPC).

Extraction by isoelectric $\mathrm{pH}$ led to $69.20 \%$ and $56.80 \%$ increases in crude protein content for the crambe and sunflower protein concentrates, respectively, compared with their respective meals (Table II). The protein and lipid contents of crambe meal, for variety FMS Brilhante, was different to related by Souza et al. (2009) and Ítavo et al. (2015), where the CP content of crambe meal was similar to the protein content of the crambe press cake. 
TABLE I

The protein and lipid compositions, as well as the percent yield relative to the meals, of the protein concentrates isolated from sunflower and crambe meals using three different extraction methods: isoelectric (pHi), acid pH and alkaline pH.

\begin{tabular}{|c|c|c|c|}
\hline \multirow{3}{*}{$\begin{array}{c}\text { Parameter } \\
\text { g/100g }\end{array}$} & \multicolumn{3}{|c|}{${ }^{1} \mathrm{CMPC}$} \\
\hline & \multicolumn{3}{|c|}{ Extraction method } \\
\hline & pHi extraction & Acid $p H$ extraction & Alkaline $p H$ extraction \\
\hline Crude protein & $52.21 \pm 0.58^{\mathrm{a}}$ & $29.16 \pm 0.80^{\mathrm{b}}$ & $27.46 \pm 1.61^{\mathrm{b}}$ \\
\hline Lipids & $12.30 \pm 1.87^{\mathrm{a}}$ & $7.05 \pm 0.63^{\mathrm{b}}$ & $8.80 \pm 0,71^{\mathrm{b}}$ \\
\hline \multirow[t]{2}{*}{ Yield } & $50.32 \pm 0.63^{\mathrm{a}}$ & $44.50 \pm 0.64^{\mathrm{b}}$ & $48.22 \pm 0.46^{\mathrm{b}}$ \\
\hline & \multicolumn{3}{|c|}{${ }^{2} \mathrm{SMPC}$} \\
\hline Parameter & \multicolumn{3}{|c|}{ Extraction method } \\
\hline $\mathrm{g} / \mathbf{1 0 0 g}$ & pHi extraction & Acid $p H$ extraction & Alkaline $p H$ extraction \\
\hline Crude protein & $54.58 \pm 0.96^{\mathrm{a}}$ & $47.48 \pm 0.64^{\mathrm{b}}$ & $47.36 \pm 0.64^{\mathrm{b}}$ \\
\hline Lipids & $6.28 \pm 0.64^{\mathrm{a}}$ & $3.44 \pm 0.62^{\mathrm{b}}$ & $1.90 \pm 0.14^{\mathrm{b}}$ \\
\hline Yield & $48.30 \pm 1.45^{\mathrm{a}}$ & $45.20 \pm 1.33^{\mathrm{b}}$ & $37.83 \pm 1.17^{\mathrm{c}}$ \\
\hline
\end{tabular}

*Average values followed by different letters were found to be significantly different using Tukey's test $(\mathrm{p}<0.05)$.

${ }^{1}$ CMPC: Crambe Meal Protein Concentrate.

${ }^{2}$ SMPC: Sunflower Meal Protein Concentrate.

PHYSICAL PROPERTIES, PHENOLIC COMPOUNDS AND AMINO ACIDS CONTENTS

Furthermore, it was observed that the isoelectric $\mathrm{pH}$ protein concentration method was effective at decreasing total phenolic content by approximately $50 \%$ compared with the original meal. The WHC and $\mathrm{OHC}$ of the meals and protein concentrates. A higher percentage of polar amino acids are most likely responsible for the increased hydration capacity (Table II) observed in the SMPC $(1,717.9$ g. $\left.\mathrm{kg}^{-1}\right)$ relative to CMPC $\left(1,403.7 \mathrm{~g} \cdot \mathrm{kg}^{-1}\right)$.

In this study protein concentration using the pHi method increased lysine and methionine levels by 1.5 - and 2.22-fold, respectively in CMPC, and by 1.42 - and 2.87 -fold, respectively in SMPC (Table III).

In the Figure 2 are illustrates the foaming capacity and foam stability (in \% volume increase). The CMPC showed a foaming capacity of $15 \%$, with the foam stabilizing at $6 \%$ after 90 minutes. The SMPC showed a foaming capacity of $4 \%$ in the zero time and there was no stability in other times.

\section{TABLE II}

Chemical composition, functional properties and total phenols of the crambe and sunflower meals and the protein concentrates isolated from the meals using the isoelectric $\mathrm{pH}$ method.

\begin{tabular}{|c|c|c|c|c|}
\hline \multirow[t]{2}{*}{ Parameter } & $\begin{array}{c}\text { Crambe } \\
\text { meal }\end{array}$ & $\begin{array}{c}\text { Sunflower } \\
\text { meal }\end{array}$ & $\mathrm{CMPC}^{1}$ & $\mathrm{SMPC}^{2}$ \\
\hline & \multicolumn{4}{|c|}{ g. $\mathrm{kg}^{-1}$ of dry matter } \\
\hline Dry matter & $964.4^{\mathrm{a}}$ & $880.6^{\mathrm{b}}$ & $964.7^{\mathrm{a}}$ & $951.8^{\mathrm{a}}$ \\
\hline Moisture & $36.0^{\mathrm{b}}$ & $119.4^{\mathrm{a}}$ & $35.3^{\mathrm{b}}$ & $48.2^{\mathrm{b}}$ \\
\hline Ash & $96.99^{\mathrm{a}}$ & $108.7^{\mathrm{a}}$ & $63.5^{\mathrm{b}}$ & $73.7^{\mathrm{b}}$ \\
\hline $\begin{array}{l}\text { Crude } \\
\text { Protein }\end{array}$ & $301.88^{c}$ & $381.6^{\mathrm{b}}$ & $522.1^{\mathrm{a}}$ & $545.8^{\mathrm{a}}$ \\
\hline Lipids & $66.4^{\mathrm{b}}$ & $16.2^{\mathrm{c}}$ & $127.5^{\mathrm{a}}$ & $66.7^{\mathrm{b}}$ \\
\hline $\begin{array}{c}\text { WHC } \\
\text { (g water.g } \\
\left.\text { product }^{-1}\right)^{3}\end{array}$ & $4.02^{b}$ & $4.53^{\mathrm{a}}$ & $1.40^{\mathrm{d}}$ & $1.72^{\mathrm{c}}$ \\
\hline $\begin{array}{c}\text { OHC } \\
(\mathrm{g} \text { oil.g } \\
\left.\text { product }^{-1}\right)^{4}\end{array}$ & NA* & $\mathrm{NA}^{*}$ & $1.73^{\mathrm{a}}$ & $1.61^{\mathrm{b}}$ \\
\hline $\begin{array}{c}\text { Total } \\
\text { Phenols }\end{array}$ & $40.2^{\mathrm{a}}$ & $38.5^{\mathrm{b}}$ & $20.1^{\mathrm{c}}$ & $18.5^{\mathrm{d}}$ \\
\hline
\end{tabular}

Average values followed by different letters were found to be significantly different using Tukey's test $(p<0.05) .{ }^{1}$ CMPC: Crambe Meal Protein Concentrate. ${ }^{2}$ SMPC: Sunflower Meal Protein Concentrate. ${ }^{3} \mathrm{WHC}$ : Water Holding Capacity: g water/ g product. ${ }^{4} \mathrm{OHC}$ : Oil Holding Capacity: g oil /g product. 5 (mg/L) Gallic Acid. *No Analyzed. 
TABLE III

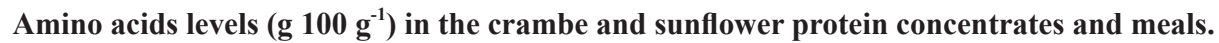

\begin{tabular}{|c|c|c|c|c|}
\hline Amino acids & Crambe meal & Sunflower meal & $\mathrm{CMPC}^{1}$ & $\mathrm{SMPC}^{2}$ \\
\hline \multicolumn{5}{|c|}{ 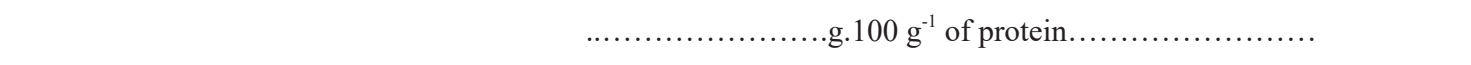 } \\
\hline Lysine & $1.71^{\mathrm{b}}$ & $1.23^{\mathrm{c}}$ & $2.57^{\mathrm{a}}$ & $1.74^{\mathrm{b}}$ \\
\hline Methionine+cysteine & $0.91^{\mathrm{c}}$ & $0.66^{\mathrm{d}}$ & $2.02^{\mathrm{a}}$ & $1.89^{\mathrm{b}}$ \\
\hline Threonine & $1.20^{\mathrm{c}}$ & $1.15^{\mathrm{c}}$ & $2.47^{\mathrm{a}}$ & $1.64^{\mathrm{b}}$ \\
\hline Valine & $1.86^{\mathrm{c}}$ & $1.64^{\mathrm{d}}$ & $2.90^{\mathrm{a}}$ & $2.61^{\mathrm{b}}$ \\
\hline Leucine & $2.05^{\mathrm{d}}$ & $2.24^{\mathrm{c}}$ & $3.45^{\mathrm{a}}$ & $3.00^{\mathrm{b}}$ \\
\hline Phenylalanine & $1.91^{\mathrm{b}}$ & $1.41^{\mathrm{c}}$ & $2.24^{\mathrm{a}}$ & $1.93^{\mathrm{b}}$ \\
\hline Histidine & $0.41^{\mathrm{d}}$ & $0.81^{\mathrm{c}}$ & $1.42^{\mathrm{a}}$ & $1.03^{\mathrm{b}}$ \\
\hline Arginine & $2.35^{\mathrm{d}}$ & $2.45^{\mathrm{c}}$ & $2.89^{\mathrm{b}}$ & $3.28^{\mathrm{a}}$ \\
\hline
\end{tabular}

Average values followed by different letters were found to be significantly different using Tukey's test (p<0.05). ${ }^{1} \mathrm{CMPC}$ : Crambe Meal Protein Concentrate. ${ }^{2}$ SMPC: Sunflower Meal Protein Concentrate.

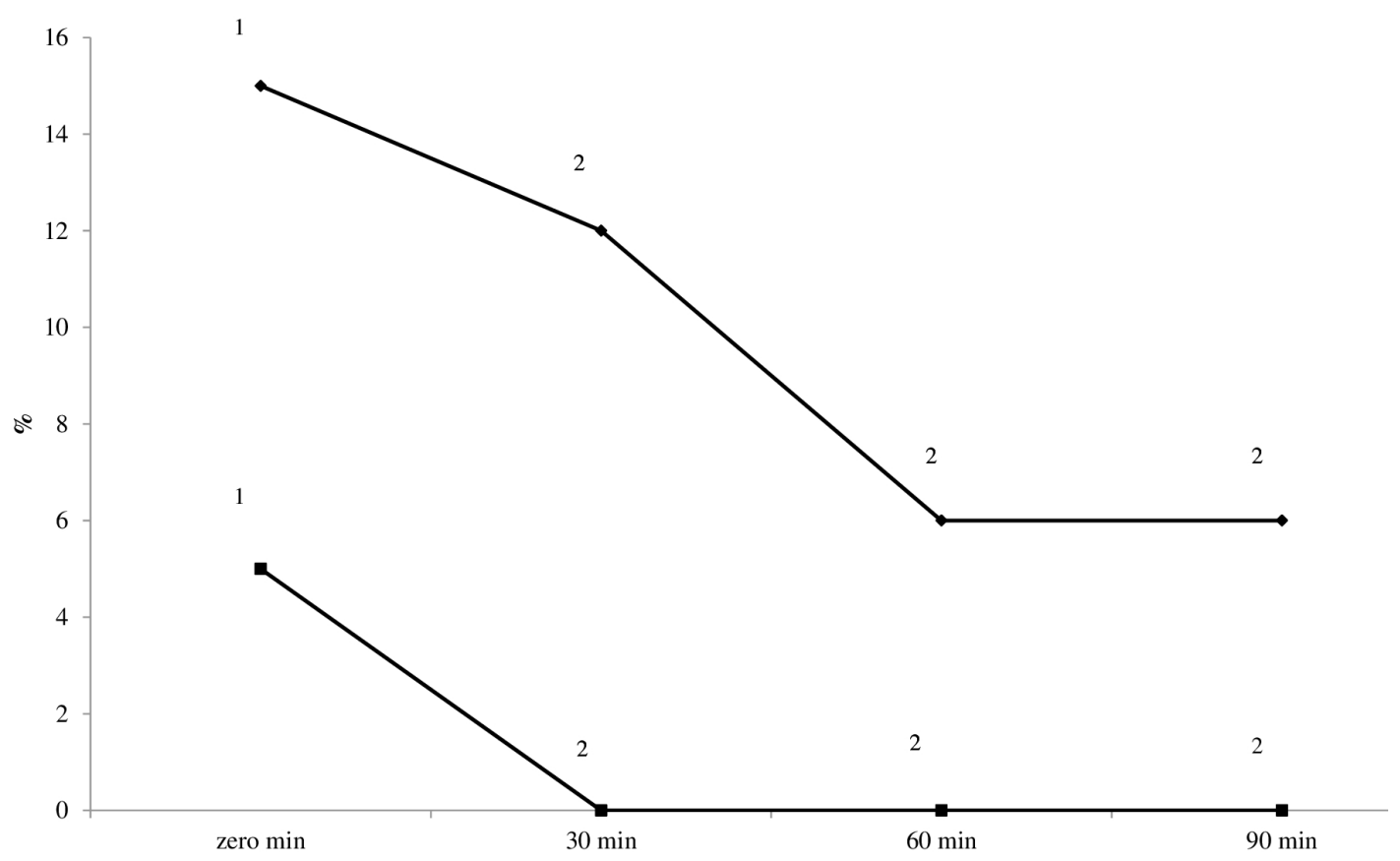

Figure 2 - The foaming properties of the protein concentrates derived from the crambe and sunflower meals. (1) Foaming capacity, initial volume (\%). (2-4) Foam stability (\% volume reduction). 


\section{DISCUSSION}

The protein concentration techniques we tested vary in their efficiency based on the chemical nature of the protein in the ingredients, and more specifically the properties of the radicals in the primary amino-acid structure. This efficiency difference for extraction by $\mathrm{pHi}$ occurred because these meals primarily contain amino acids with isoelectric points between 5.0 and 7.0 (Lehninger et al. 2004), making this an ideal technique for protein concentration in vegetable meals.

The chemical treatment of concentrates increased the lipid contents (Table II) due decreased the fiber contents and, possibly, by lipid-protein interactions and the formation of hydrophobic lipoproteins (Araújo 2008). The amino acid profiles of plant components can vary based on cultivar type, crop/pest control methods and industrial processes (Andriguetto 1988, Mandarino 1992, Ledoux et al. 1999, Tavernari 2010). The amino acids contents increased, due fiber contents decreased in the final product (protein concentrate). However, some chemical processing for protein concentration, such as acetylation, which may lower the methionine and lysine content of the protein concentrate (Linden and Lorient 1996).

In addition to such variations, plant sources are normally deficient in lysine and methionine, two amino acids that are of great importance to animal growth and health. The fact that lysine and methionine levels were increased - which are considered to be the most limiting amino acids in fish-feed protein sources (Tusche et al. 2011) demonstrates that the $\mathrm{pHi}$ method is efficient not only for increasing protein concentration but also for improving protein quality of the sources used in this study.

The phenolic compounds are present in the fibrous fractions of a variety of foods and are generally considered to be either indigestible or poorly digestible, limiting the use of these proteins
(Salgado et al. 2012) for fish feeding (Bergamin et al. 2013). The phenolic compounds present antioxidant potential, which may be important in the process of storage and feed ingredients, particularly in products with high lipid content. However, Hernández et al. (2014) analyzing antioxidant potential of natural products (Rosmarinus officinalis, Thymus zygis and Thymbra capitata) in extruded feeds, related no differences in lipid peroxidation process when essential oils used with different levels of phenolic compounds, probably by thermal procession in extrusion.

Furthermore, phenolic compounds can affect the color, flavor and nutritional quality of fish feed ingredients (Silva and Silva 1999). Conventional processes for protein extraction and concentration can result in products with low nutritional quality, which may be related to covalent bonding between phenolic compounds and reactive protein residues, such as cysteine or lysine, under alkaline and highheat conditions (Pickardt et al. 2009). However, the optimal protein concentration and extraction method used in this study was carried out at the protein isoelectric point, thus increasing the potential uses of crambe and sunflower protein concentrates.

Protein functionality is defined by the physical and chemical properties that affect protein behavior during food processing, storage and preparation (Araújo 2008). These processes include emulsification, hydration, foam formation and solubility. The hydration property of a protein is partially related to its amino acid composition. In particular, nonpolar amino acid residues are generally located inside proteins, where they cannot be hydrated. Therefore, the hydration property of a protein is largely determined by hydrophilic amino-acid residues on the surface of proteins (Damodaran and Paraf 1997, Araújo 2008).

With this in mind, OHC, as shown in Table II, represents an inverse measurement of WHC. Dench et al. (1981) reported that oil absorption 
varies according to the number of exposed hydrophobic groups on the protein. It has also been suggested that nonpolar side chains on proteins have an affinity for the hydrophobic chains of oil molecules, contributing to oil absorption (Donadel and Prudencio-Ferreira 1999).

Besides nutritional aspects, physicochemical characteristics of the ingredients exert a decisive impact on the technological quality and digestibility of the aquatic feeds (Glencross et al. 2007). The parameters of hardness, stability in water, buoyancy and storage time of fish feed are influenced by the ability of the raw materials to hydrate and bind to fat (Draganovic et al. 2011). Ingredients at lower hydration capacity require less water during the feed extrusion procedure (Draganovic et al. 2014). The lower WHC observed for protein concentrates in the present study, can form pellets which require less water for extrusion, thus favoring energy expenditure and less waste to the environment (Draganovic et al. 2014)

Stronger emulsifying and foaming properties as well as increased lipid levels and oil holding capacities make the formation of animal feed into pellets more difficult (González-Pérez and Vereijken 2007), when oil levels exceed $7 \%$ on rations.

A foam is a colloidal dispersion in which a gas is dispersed throughout a liquid or solid phase, and one can be created when air molecules are captured and trapped by proteins present in a liquid (Fennema 2000). The sunflower protein concentrate showed a foaming capacity of $4 \%$ but was not able to maintain stable foam after the initial formation. Globulins generally aid in foam formation, whereas albumins facilitate foam fixation and stabilization (Belitz et al. 2009). However, the most abundant type of globulin in sunflower meal is the $12 \mathrm{~S}$ form, which can be distinguished from the other globulins by its high isoelectric $\mathrm{pH}$ and differences in hydrophobicity and dissociative behavior, among other characteristics (Linden and Lorient 1996).
Moreover, this globulin represents $17 \%$ of all sunflower proteins (Mandarino 1992) and significantly affects the foaming properties of this product. Emulsification and foam-formation capacities are important parameters to consider when formulating extruded animal feed, as they can lead to the incorporation of air and the expansion of protein molecules during extrusion.

\section{CONCLUSIONS}

The isoelectric $\mathrm{pH}$ protein concentration method is more efficient than either the acid or alkaline $\mathrm{pH}$ methods for processing crambe and sunflower meals, and it can produce novel products with higher protein contents and enhanced amino acid profiles compared with the original raw materials. Furthermore, the techniques described here reduce total phenolic compounds, which are antinutritional factors that limit the use of vegetable byproducts as fish feed ingredients.

\section{ACKNOWLEDGMENTS}

The authors thank the Programa de Pós-Graduação em Zootecnia - Universidade Federal de Santa Maria (UFSM) and the Conselho Nacional de Desenvolvimento Científico e Tecnológico (CNPq) for the research productivity fellowships (Leila Picolli da Silva), the Master's program fellowship (Naglezi de Menezes Lovatto) and the undergraduate scientific research program fellowship (Bruno Bianch Loureiro). We also thank the Ministério de Ciência e Tecnologia (MCT/ CNPq) of the Fundo Setorial do Agronegócio (CT-AGRO - MCT/CNPq) and the Ministério da Pesca e Aquicultura (MPA). Finally, the authors would like to thank the Giovelli Company for the sunflower meal donations.

\section{REFERENCES}

ANDRIGUETTO JM. 1988. Nutrição Animal. 4ª ed., São Paulo, Nobel, 395 p. 
AOAC. 2000. Official Methods of Analysis. $16^{\text {th }}$ ed., Association of Official Analytical Chemists. Arlington, $1137 \mathrm{p}$.

ARAÚJO JMA. 2008. Química de Alimentos - Teoria e Prática. $4^{\mathrm{a}}$ ed., Viçosa: editora, UFV, 478 p.

BELITZ HD, GROSCH W AND SCHIEBERLE P. 2009. Food Chemistry. $4^{\text {th }}$ revised and extended Edition. SpringerVerlag, $1070 \mathrm{p}$.

BERGAMIN GT, VEIVERBERG CA, SILVA LP, PRETTO A, SIQUEIRA LV AND RADÜNZ NETO J. 2013. Extração de antinutrientes e aumento da qualidade nutricional dos farelos de girassol, canola e soja para alimentação de peixes. Ciênc Rural 43(10): 1878-1884.

BLIGH EG AND DYER W J. 1959. A rapid method of total lipid extraction and purification. Can J Biochem Phys 37: 911-917.

COFFMANN CN AND GARCIA VV. 1977. Functional properties and amino acid content of a protein isolated from mung bean flour. J Food Technol 12: 473-484.

DAMODARAN S AND PARAF A. 1997. Food proteins and their applications in Food proteins: An overview, New York: Marcel Dekker, p. 1-21.

DENCH JE, RIVAS RN AND CAYGIL JC. 1981. Selected functional properties of sesame (Sesame indicum L) flour and two protein isolates. J Sci Food Agr 32: 557-564.

DONADEL ME AND PRUDENCIO-FERREIRA SH. 1999. Propriedades funcionais de concentrado proteico de feijão envelhecido. Ciênc Tecnol Aliment 19(3): 380-386.

DONGMEZA E, STEINBRONN S, FRANCIS G, FOCKEN U AND BECKER K. 2009. Investigations on the nutrient and antinutrient content of typical plants used as fish feed in small scale aquaculture in the mountainous regions of Northern Vietnam. Anim Feed Sci Tech 149: 162-178.

DRAGANOVIC V, BOOM RM, JONKERS J AND GOOT AT. 2014. Lupine and rapeseed protein concentrate in fish feed: A comparative assessment of the techno-functional properties using a shear cell device and an extruder. J Food Eng 126: 178-189.

DRAGANOVIC V, GOOT AT, BOOM R AND JONKERS J. 2011. Assessment of the effects of fish meal, wheat gluten, soy protein concentrate and feed moisture on extruder system parameters and the technical quality of fish feed. Anim Feed Sci Tech 165: 238-250.

EMBRAPA - EMPRESA BRASILEIRA DE PESQUISA AGROPECUÁRIA. 2011. Girassol. Disponível em: $<$ http// WWW.cnpso.embrapa.br/índex.php?op_pag=54\&cod_ pai $=38>$. Acesso em 16 de novembro de 2011 .

FENNEMA OR. 2000. Química de los Alimentos. $1^{\circ}$ ed., Zaragoza, editora Acribia, $1280 \mathrm{p}$.

GLENCROSS B, HAWKINS W, EVANS D, RUTHERFORD N, DODS K, MCCAFFERTY P AND SIPSAS S. 2007. Evaluation of the influence of drying process on the nutritional value of lupin protein concentrates when fed to rainbow trout (Oncorhynchus mykiss). Aquaculture 265: 218-229.

GONZÁLEZ-PÉREZ S AND VEREIJKEN JM. 2007. Sunflower proteins: overview of their physicochemical, structural and functional properties. J Sci Food Agric 87(12): 2173-2191.

HARDY RW. 2010. Utilization of plant proteins in fish diets: effects of global demand and supplies of fish meal. Aquac Res 41: 770-776.

HERNÁNDEZ A, GARCÍA-GARCÍA B, JORDÁN MJ AND HERNÁNDEZ MD. 2014. Natural antioxidants in extruded fish feed: Protection at different storage temperatures. Anim Feed Sci Tech 195: 112-119.

INSTITUTO ADOLFO LUTZ. 1985. Normas analíticas do Instituto Adolfo Lutz: métodos químicos e físicos para análise de alimentos. $3^{\mathrm{a}}$ ed., São Paulo: IAL v1, 368 p.

ÍTAVO LC, SOARES CM, ÍTAVO CC, DIAS AM, PETIT HV, LEAL ES AND SOUZA AD. 2015. Calorimetry, chemical composition and in vitro digestibility of oil seeds. Food Chem 185: 219-225.

LEDOUX DR, BELYEA RL, WALLIG MA AND TUMBLESON ME. 1999. Effects of feeding crambe meal upon intake, gain, health and meat quality of broiler chicks. Anim Feed Sci Tech 76: 227-234.

LEHNINGER AL, NELSON DL AND COX MM. 2004. Principles of Biochemistry. Fourth Edition, New York: W. H. Freeman, $1119 \mathrm{p}$.

LINDEN G AND LORIENT D. 1996. Bioquímica Agroindustrial. Editora Acribia S/A, 380 p.

MANDARINO JMG. 1992. Características bioquímicas e nutricionais do óleo e do farelo de girassol. Londrina: EMBRAPA - CNPSo, 25 p.

MARIOD AA, FATHY SF AND ISMAIL M. 2010. Preparation and characterization of protein concentrates from defatted kenaf seed. Food Chem 123: 747-752.

MODESTI CF, CORRÊA AD, OLIVEIRA ED, ABREU CMP AND SANTOS CD. 2007. Caracterização de concentrado proteico de folhas de mandioca obtido por precipitação com calor e ácido. Ciênc Tecnol Aliment 27(3): 464-469.

NAYLOR RL ET AL. 2009. Feeding aquaculture in an era of finite resources. Proceedings of the National Academy of Sciences of the United States of America- PNAS 106(36): 15103-15110.

OKEZIE B AND BELLO AB. 1988. Physicochemical and functional properties of winged beans flour and isolated compared with soy isolated. J Food Sci 53: 450-454.

PICKARDT C, NEIDHARTA S, GRIESBACHB C, DUBEA M, KNAUFB U, KAMMERERA DR AND CARLEA R. 2009. Optimization of mild-acidic protein extraction from defatted sunflower (Helianthus annus L.) meal. Food Hydrocoll 23: 1966-1973. 
SALGADO PR, DRAGO SR, ORTIZ SEM, PETRUCCELLI $\mathrm{S}$, ANDRICH O, GONZÁLEZ RJ AND MAURI AN. 2012. Production and characterization of sunflower (Helianthus annuus L.) protein-enriched products obtained at pilot plant scale. LWT - Food Science Technol 45: 6572.

SILVA JMG, ESPE M, CONCEIÇÃO LEC, DIAS J, COSTAS B AND VALENTE LMP. 2010. Feed intake and growth performance of Senegalese sole (Solea senegalensis Kaup, 1858) fed diets with partial replacement of fish meal with plant proteins. Aquac Res 41: 20-30.

SILVA MR AND SILVA MAAP. 1999. Aspectos nutricionais de fitatos e taninos. Rev Nutr 12(1): 5-19.

SMITH AK, JOHNSON VL AND BECKEL AC. 1946. Linseed proteins alkali dispersion and acid precipitation. $\mathrm{J}$ Ind Eng Chem 38: 353-356.

SOUZA ADV, FÁVARO SP, ÍTAVO LCV AND ROSCO R. 2009. Chemical characterization of seeds and press cakes of physic nut, radish and crambe. Pesq Agropec Bras 44: 1328-1335.
TAVERNARI FC, MORATA RL, RIBEIRO JÚNIOR V, ALBINO LFT, DUTRA JÚNIOR WM AND ROSTAGNO HS. 2010. Avaliação nutricional e energética do farelo de girassol para aves. Arq Bras Med Vet Zootec 62(1): 172177.

TUSCHE K, BERENDS K, WUERTZ S, SUSENBETH A AND SCHULZ C. 2011. Evaluation of feed attractants in potato protein concentrate based diets for rainbow trout (Oncorhynchus mykiss). Aquaculture 321: 54-60.

WATERHOUSE A. 2001. Folin-Ciocalteau Micro Method for Total Phenol in Wine Department of Viticulture \& Enology University of California, Davis. Available in: http:// waterhouse.ucdavis.edu/phenol/folinmicro.htm, accessed April, 2013.

WHITE J, HART R AND FRY J. 1986. An Evaluation of The Waters Pico-Tag System For The Amino-Acid-Analysis Of Food Materials. J Automatic Chem 8: 170-177.

WILSON RP. Amino-acids and protein. In: Halver JE and Hardy RW. Fish nutrition. $3^{\text {rd }}$ ed., USA: Elsevier Science, 2002, p. 144-175. 